The afternoon was devoted to certain inter-sectional meetings at the Centre Universitaire, and the organisation of sectional programmes at the Lycée de Garçons which had just been rebuilt. Tuesday, Wednesday and Friday were occupied mainly by the work of the sections, but the proverbial hospitality of Nice was shown in the variety of entertainments arranged by the municipality, including a reception at the Villa Masséna and a concert at the Opera. Thursday was devoted to an excursion to Monaco, including visits en route to the Mont Gros observatory and the famous Augustus Monument and Museum at La Turbie.

At Monaco the afternoon was spent at the Oceanographical Institute, where the Director, Commandant Rouch, gave an account of the work of the Institute. Afterwards a visit was paid to the Jardins Exotiques with thei: extensive collection of cacti and other xerophytes.

Saturday, the last day of the Congress, concluded with an address by Commandant Rouch on French oceanographers, from Pythéas to Charcot; he recalled that it was exactly ten years since the Pourquoi Pas disappeared with Charcot and his orew.

A special feature of the Congress was the number of papers dealing with local problems, and excursions were arranged by many of the sections, including those of geology, botany, biogeography, agronomy and forestry. There was, for example, a valuable day excursion in motor coaches ascending the mountains inland from Nice to a height of 1,700 metres to view the successive altitudinal zones of the forests (at a number of places the excursionists were not allowed to walk off the road owing to unexploded mines).

The Congress was attended by many foreign delegates and also by representatives of more than forty French academies and scientific societies. The British Association was represented by Dr. Edward Hindle, one of its general secretaries, and Prof. $\mathrm{H}$. Munro Fox.

It was decided to hold the Congress for 1947 at Biarritz towards the end of September. Dr. L. Fage, professor at the National Museum of Natural History, was elected president, and Dr. Lavier, professor at the Faculty of Medicine, Paris, was appointed secretary.

E. HINDLE

\section{GROWTH OF MODERN PSYCHIATRY*}

$I^{\mathrm{N}}$

$\mathrm{N}$ his three Salmon Memorial Lectures before the New York Academy of Medicine, Dr. D. M. Levy traced the growth of modern psychiatry and showed its influence on psychiatric thought. Dr. Levy com. menced his career in the Illinois Institute for Juvenile Research in 1920. The study of delinquency was then very much under the influence of the work of Dr. William Healy, and was beginning to be applied to criminology. Healy himself was building upon the foundations laid by Meyer, Binet and Freud. Meyer had developed the view that behaviour is a reaction to environment, and under him psychiatry became the study of purpose and response. Binet had opened the way to the measurement of mental powers by his work on school-children, and Freud had stripped

* Substance of the Salmon Memorial Lectures delivered at the New York Academy of Medicine by Dr. David Mordecai Levy, director of the Infirmation Control, Division Screening Centre, U.S. Army, Germany, on November 6,13 and 20. away illusions to show the real motivation behind conduct. The result of their impact upon Healy was his book, "Mental Conflict and Misconduct".

Dr. Levy showed the development of child guidance and demonstrated it by an interesting recital of a case which attended the clinic where he then worked. The different approaches to the child's problem were studied with earnestness and enthusiasm, so that one feels, as he said, that these were exciting days and even the smallest discovery was fascinating. $\mathrm{He}$ showed how the environmentalist exploited milieu psychology and the impact of social forces upon the child's behaviour ; the psychometric testing revealed the individual's intellectual capacities, and the organic approach showed underlying physical disease. Although all these were rival methods, and to some extent still are, they have been integrated into teamwork which reveals the whole. Yet in spite of all its advances, child psychiatry is still in a formative phase.

In his second lecture, Dr. Levy discussed delinquency, and pointed out that here, on the whole, psychiatry has not made notable progress. This is partly because of the legal difficulties and the lack of institutions suitable to exploit the psychiatrist's recommendations,

Psychotherapy may be useful for the criminal, but it is prolonged, and an impractical treatment with present resources. The correction of environment is helpful, and group psychotherapy offers promise. Foster homes are useful in certain cases. When institutions are used, every member of the staff should have an understanding, non-authoritarian attitude. Delinquent children previously exposed to disciplinary measures are confused when they breathe this new air. They suspect trickery, try to discover the weak spots, attempt to escape or run amok. Finally they settle down and the remedial aspects of the new method appear.

Dr. Levy traced the gradual advances from dungeon to prison, from prison to reformatory, and showed that this was an evolution of society's attitude to the criminal from primitive vengeance, graded punishment according to the seriousness of the offence, then the acceptance of some responsibility for the delinquent behaviour, and at last to the attempt to reform him. Modern psychiatry regards crime as something curable, something from which the criminal suffers. Reform in Britain has progressed farther than in the United States, but America leads in psychiatric study and treatment. He deplored the fact that psychiatry is so often neglected, and pointed out that many penitentiaries still have no psychiatric service.

Dr. Levy discussed the inroads which lay-psychotherapists are making into psychiatry; he fears that they will cause a permanent lowering of standards.

In his last lecture, Dr. Levy demonstrated that psychiatry is progressing through various phases. At first the psychiatrist dealt only with the severe neuroses and psychoses. Then he tended to be consulted regarding personal problems by labour and management. The third phase would be an integration with industry, but it remains a remote possibility. $\mathrm{He}$ gave various interesting points regarding the relationship between foremen and workers. These have shown a gradual transition in behaviour. The first and most primitive type of relationship was when the foreman gave an order categorically. Dr. Levy called this authoritarian. A further step was when 
the foreman gave an order and explained the reason for it. This he designated transitional. Finally, when the foreman consulted the worker, asking for criticism and advice, this was a participating relationship. The older the factory and the closer the union between foreman and worker, the more the relationship tends to be a participating one.

Dr. Levy then turned to military psychiatry. This served its apprenticeship in the First World War, and in the Second World War was used much more extensively. Greater reliance was placed on sedation and abreaction. Many soldiers were saved in numerous useful capacities. Group therapy was possible, and better organisation of social contacts and recreation. Dr. Levy felt that this was distinctly an American contribution, although British psychiatrists have made it an essential part of therapy.

$\mathrm{He}$ then discussed personnel selection in Germany and the school where Germans are trained as inter. preters, secretaries, investigators, clerks, etc. More than eight hundred have received training there. He pointed out that this gave a unique chance to observe the damage the Nazi regime had done to the national character and personal adjustments. The differences in the family environment between Nazis and non. Nazis were observable.

Dr. Levy believes that the field of political psychiatry is just emerging and will be helpful in the selection of leaders in the new Germany.

\section{FORTHCOMING EVENTS}

(Meeting marked with an asterisk * is open to the public)

\section{Monday, January 6}

Institution of POST OFFICE Electrical ENGINeERs (at the Institution of Electrical Engineers, Savoy Place, Victoria Embankment, London, W.C.2), at 5 p.m.-Mr. H. R. Harbottle: "The Provision of Line Communications for the Fighting Services".

SOCIETY OF CHEMICAL INDOSTRY (at the Chemical Society, Burlington House, Piecadilly, London, W.1), at 6.30 p.m.--Dr. G. M. Bennett: "Nitration with Mixed Acids".

\section{Tuesday, January 7}

ROYAI Institution (at 21 Albemarle Street, London, W.1), at 3 p.m.-Prof. H. Hartridge, F.R.S.: "Colours and How we"See Them" (Christmas Juvenile Lectures, 5) (succeeding Lecture on Thursday, January 9).*

INSTITUTION OF ChEMICAL ENGINEERs (at the Geological Society of London, Burlington House, Piccadilly, London, W.1), at 5.30 p.m. Dr. C. C. Hall and Mr. A. H. Taylor: "Chemical Engineering Aspects of the Fischer-Tropsch Process".

\section{Wednesday, January 8}

Socterty of Chemical IndUSTry, Microbiological PANEL OF THE FOOD GROUP (joint meeting with the SOCIETY FOR APPIIED BACTERIOLOGY, at the Medical Society of London, 11 Chandos Street, London, W.1), at 2.15 p.m.-Dr. J. G. Baumgartner : "Fermentation of Lipolysis and Rancidity in Fats"; Dr. H. H. Evers: "Curing and Fermentation of Tobacco"

RoyAr SOCIETY of ARTS (at John Adam Street, Adelphi, London W.C.2), at 2.30 p.m. - Dr. J. H. Partridge : "The Story of Glass" (Dr. Mann Juvenile Lecture)

ROXaL SOCIETY OF MEDICINE, HISTORY OF MEDICINE SECTION (at 1 Wimpole Street, London, W.1), at 2.30 p.m.-Dr. A.P.Cawadias "Clinical Science in the Light of History".

MANCHESTER STATISTICAL SOCIETY (at the Reform Club, King Street, Manchester), at 5 p.m.-Mr. W. B. Reddaway: "The Census of Production".

Instimote of PeTrolevm (at Manson House, 26 Portland Place, London, W.1), at 5.30 p.M.-Mr. L. W. Leyland Cole : "Petroleum roducts in Agriculture-The Role of Petroleum in Plant Protection". ROYAL INSTITUTE OF CHEMISTRY, NEWOASTLY-UPON-TYNE AND NORTH-EAST COAST SECrION (joint meeting with the Local Section of the SOCIETY OF CHEMYCAI INDUSTRY and the INSTITUTE OF FUEL in the Chemistry Lecture Theatre, King's College, Newcastle-upon-
Tyne), at 6.30 p.m.-Dr. H. E. Crosgley : "The Inorganic Constituents of Coal".

INSTITUTION OF ELECTRICAT ENGINEERS, LONDON STUDANTS' SECrron (at Savoy Place, Victoria Embankment, London, W.C.2), at 7 p.m.-Mr. A. Mason: "Radio Transmitting Valves".
Thursday, January 9

WOMEn's ENGINEering Societr, MaNCHRSTER Branch (at the Engineers' Club, Albert Square, Manchester 2), at 6.30 p.m.-Miss Engineers' Club, Albert Square, Manchester 2),
F. B. Fairbrother: "Heating and Ventilation".

Pharmacedtiona Society (at 17 Bloomsbury Square, London, w.C.1), at 7 p.m.-Mr. F. A. Robinson: "Recent Developıents in Chromatography".

SOCIETY OF DYERS AND COLOURISTS, WRST RIDING SECTION (at the Great Northern Victoria Hotel, Bradford), at 7.15 p.m.-Dr. E. G. H. Carter: "Testing as an Aid to Efficient Finishing".

Chemroal SOCreTY (at Burlington House, Piccadilly, London, W.1) at 7.30 p.m. - Mr. B. C. Saunders : "Toxic Fluorophosphonates and "related Compounds"; Mr. N. J. Cartwright and Mr. R. D. Haworth "Some Aspects of the Oxidation and the Dimerisation of Propenyl-

Chemical Society, Manchester Section (joint meeting with the Local Section of the ROYAL INSTITUTE OF CHEMISTRY, in the Chemistry Department, The University, Manchester), at 7.30 p.m.-Dr.

\section{Friday, January 10}

Textile Instrtute, Lancashire Section (at 16 St. Mary's Parsonage, Manchester 3), at 1 p.m.-Mr. W. E. Swale. "Public Electricity Supply and its Application in the cotton Textile Industry".

INSTITUTION OF ChEMXCAL ENGINEERS, NORTH-WESTERN BRANCH (in Reynolds Hall, College of Technology, Manchester), at 3 p.m.Annual General Meeting. Mr. C. E. Rowe : "Aspects of Pilot Plant Development".

Royat Astroxomicai Society (at Burlington House, Piceadilly, London, W.1), at 4.30 p.m.--Scientiflc Papers.

PHYSICAL SOCIETY (in the Lecture Theatre, Science Museum, Exhibition Road, London, S.W.7), at 5 p.m.--Presentation of the 2nd Charles Vernon Boys Prize to Mr. Robert W. Sutton; "Kelvin, Master of Measurement" (sound film).

Institution of MEChanical ENGinkers (at Storey's Gate, St. James's Park, London, S.W.1), at 5.30 p.m.-Dr. D. M. Smith : "The Development of an Axial Flow Gas Turbine for Jet Propulsion": Mr. K. Watson Todd: "Practical Aspects of Cascade Wind Tunnel Research".

OIl and Colour Chemists' Association, Manchester Section (at the Engineers' Club, Albert Square, Manchester), at 6.30 p.m.Mr. A. Hancock and Mr. T. F. Brown": "Paint Settling-a Suggested Method for Determining the Settling Properties of Paints".

INSTITUTE of PHYSICS, MANCHESTER AND DISTRICT BRANCH (joint meeting with the INSTITUTION OF ELECTRONICS, N.W. ENGLAND SECTION, in the New Physics Theatre, The University, Manchester), at 7 p.m.--Prof. D. R. Hartree, F.R.S.: "Recent Developments of Calculating Machines in U.S.A.

TEXTILE INstitute, BolToN BRanck (at the Municipal Technical College, Bolton), at 7.30 p.m.-Mr. G. K. Hughes: "Textiles and their Launderability".

INSTITUTE OF PHYSICS, MidLAND BRANCH (at the Imperial Hotel, Birmingham).-Prof. J. M. Meek: "The Nature of the Electric Spark".

\section{Saturday, January II}

Association of BRirtisH ZoOLOGISTS (at the Zoological Society of London, Regent's Park, London, N.W.8), at 10 a.m. -Twelfth Possibilities and Training".

INSTITUTE OF Physics, Electronics Group (joint meeting with the SOUTH WALES BRANCH OF THE INSTITUTE OF PHYSICS, in University College, Cardiff), at 3.30 p.m.-Dr, F. A. Vick: "Contact Potentials".

\section{APPOINTMENTS VACANT}

ApPIICATIONS are invited for the following appointments on or before the dates mentioned:

ASSISTANT STRUCTURAL ENGINEER (temporary) in the Ministry of Finance-The Assistant Secretary (Establishments), Ministry of Finance, Stormont, Belfast, quoting S.B.202/46 (January 10),

ASSISTANT TECHNICAT SECRETARY (male) by the Iron Making Division of the Association-The Personnel Officer, British Iron and Steel Research Association, 11 Park Lane, London, W.1, endorsed 'ron Making Division' (January 11).

HEAD OF THE DEPARTMENT OF HORTICULTURE at the Yorkshire Institute of Agriculture, Askham Bryan, York-The Joint Clerk, Yorkshire Council for Agricultural Education, County Hall, Beverley, Yorks. (January 11).

EDITORIAX OFFICER for the Society's Journal and other publications-The Hon. Secretary, Society of Dyers and Colourists, 32-34 Piccadilly, Bradford, Yorks., endorsed 'Editorial Officer' (January 11). GRADUATE MaSTERS for Government Secondary Schools, Seychelles Islands, to teach $(a)$ BIOLOGY AND GENERAL SCIENCE, $(b)$ MATHEMATICS up to School Certificate standard and JUNIOR GENERAL SCIENCE, (c) GEOGRAPHY, HISTORY and CrVICS-The Director of Recruitment, Colonial Service, 15 Victoria Street, London, S.W.1 (January 11). Professional Forksters in the New Zealand State Forest Service $\rightarrow$ The High Commissioner for New Zealand, 415 Strand, London, W.C.2 (January 12)

LECTURER IN HUMANITY in the United College, St. Andrews-The Secretary, The University, St. Andrews (January 15).

DIRECTOR OF RESEARCH-The Secretary, British Baking Industries' Research Association, Wellington House, 125-130 Strand, London, W.C.2 (January 15).

HEAD OF THE DEPARTMENT OF Agrlocltural ECoNomics, and an Assistant Agrioulturat ECoNomist-The Principal, Midland Agricultural College, Sutton Bonington, Loughborough (January 15). 